\title{
En kliniker og en bayesianer
}

\author{
Som klinikere jobber vi i usikkerhet og sannsynliggjør diagnoser og behandling. Men hvordan sannsynliggjør \\ og resonnerer vi? Oftere enn vi tror gjør vi intuitive vurderinger og er sårbare for våre kognitive skjevheter. \\ En bayesiansk forståelse reflekterer ikke bare hvordan vi tenker som klinikere, men er også et verktøy for \\ å gjøre bedre kliniske sannsynlighetsvurderinger.
}

Brage Brakedal

brage.brakedal@helse-bergen.no

> Se lederartikkel side 1424

Hvis du er en dyktig kliniker, er du en dyktig bayesianer. Som lege resonnerer du bayesiansk når du vurderer en pasient, og mye gjøres ubevisst. Uten å være klar over det bruker du enkel statistisk sannsynlighetsresonnering i din kliniske hverdag, bayesiansk resonnering, og du gjør det imponerende bra. Du vurderer fortløpende differensialdiagnostiske muligheter i lys av anamnestisk informasjon og kliniske funn. Men når det kliniske arbeidet blir vanskelig, bryter våre heuristiske tommelfingerregler ned og vi blir stående i ukjent farvann og vurdere sannsynlighet som vi har liten intuitiv forståelse for. Også gjenkjennelige situasjoner er sårbare for feilvurderinger på grunn av en rekke iboende «kognitive skjevheter » vi alle har. Ved å bli bevisst på hvordan vi resonnerer klinisk og hvilke kognitive sirener som finnes, vil vi lettere hjelpe oss selv å navigere.

\section{Hva er en bayesianer?}

Dine forventninger justeres fortløpende av ny informasjon sett $\mathrm{i}$ lys av din erfaring. Thomas Bayes, en engelsk prest og matematiker, formulerte dette matematisk i det som er nå kjent som Bayes' teorem: vurdering av nåværende sannsynlighet utgår fra forutgående sannsynlighet. Har pasienten din brystsmerter, vurderer du sannsynligheten for kardial iskemi annerledes om han er 70 år og storrøyker enn om han er 25 år og sunn mosjonist (1). Sannsynligheten vil så justeres ut ifra tilleggsinformasjon som presenterer seg enten det er ved anamnesen, EKG eller bildeundersøkelser. Sannsynligheten oppdateres fortløpende og Bayes' teorem forklarer dette matematisk. Underbevisst tillegger du informasjon og prøvesvar forskjellig betydning som du bruker til å justere hvor sannsynlig ulike differensialdiagnoser er. Du ser prøvesvar og ny informasjon i sammenheng med forutgående informasjon og klinisk erfaring. Selv om du ikke tenker tall høyt, er du en statistisk kalkulator av omtrentlige sannsynligheter, og du sannsynliggjør og resonnerer fortløpende. Selv om vår heuristiske sannsynlighetsvurdering er imponerende, har vi ikke mer intuitiv forståelse for kompleks sannsynlighet enn vi har intuisjon for kvantefysikkens prinsipper. La oss se på noen eksempler.

\section{Hva er sannsynligheten?}

Blant 23 personer, hva er sannsynligheten for at minst to personer skal ha bursdag på samme dag? Omformulert og anvendt: Hva er sannsynligheten for at to unge pasienter skal bli innlagt på Haukeland universitetssykehus samme dag med hjerneinfarkt i løpet av et år (2)? Vi vil gjette at sannsynligheten er svært lav. Men sannsynligheten for begge situasjoner er over $50 \%$. Intuitivt virker dette feil; det er få hendelser og det er mange dager. Det vi overser, er hvor mange måter man kan pare to begivenheter sammen. Dette problemet omtales ofte som bursdagsparadokset (3) og illustrerer hvor vanskelig det er å vurdere kompleks sannsynlighet intuitivt.

Et annet kjent problem som illustrerer feilbar intuisjon og som har lurt flere matematikere, er Monty Hall-problemet (4) (fig 1): Du får presentert tre luker. Bak én av lukene er det en premie, mens de to andre er tomme. Du velger en luke, men før det avsløres hva som er bak luken, får du vite at en av de resterende lukene er tomme. Du får nå valget om å kunne beholde din opprinnelige luke eller å bytte. Intuitivt virker det som sannsynligheten for gevinst uansett er 50\%. I virkeligheten er sannsynligheten $66 \%$ for gevinst hvis du bytter luke. Vår intuisjon av kompleks sannsynlighet er ekstrapolert fra vår forståelse av enkel sannsynlighet.

Et annet kjent problem er Simpsons paradoks (5). Tabell 1 viser data fra Charig og medarbeideres studie over behandling av nyrestein (6). Tabellen viser at behandling $\mathrm{B}$ er bedre når man ser på alle nyresteiner samlet, mens behandling A er bedre for hver subtype av nyrestein. Både behandling A og B virker å være best, men hvilken behandling er faktisk best? Svaret er A, men det er ikke intuitivt.
Slike paradokser er mer enn intellektuelle armhevinger, de illustrerer våre intuitive begrensninger for kompleks sannsynlighet og statistikk. Alle de tre overnevnte problemene har entydige løsninger. Kunsten er å gjenkjenne hva som er komplekst og usikkert. Gjenkjenner du det, må du frita ditt enteriske nervesystem fra sannsynlighetsregning og i stedet gå analytisk til verks.

\section{Diagnostiske skjevheter}

Hvor sårbar er din diagnostiske resonneringsevne for «diagnostiske skjevheter»? Kan du vurdere alle symptomer og tegn objektivt? Litteraturen tyder på at du ikke kan det $(7,8)$. Har du en tentativ diagnose, vil du tolke bekreftende tegn som viktigere enn de faktisk er (bekreftelsesskjevhet). Sannsynligheten for å vurdere et positivt mammogram som malignt er større - selv om utgangsrisikoen til vedkommende er veldig lav (representasjonsskjevhet). Starter du med antihypertensiver hos en pasient ved første legevisitt og deretter måler et lavere blodtrykk på neste visitt, vil du tolke reduksjonen som et resultat av behandlingen i stedet for å erkjenne at prøveverdier over tid vil gå mot gjennomsnittet (regresjon mot gjennomsnittet). Har du ofte pasienter med hjerneinfarkt, vil du overvurdere sannsynligheten for at din pasient har hjerneinfarkt (tilgjengelighetsskjevhet). Ser vi tilbake på hvor sannsynlig en diagnose var ut ifra de kliniske funnene, vil vi overestimere sannsynligheten (tilbakeblikkskjevhet). Er en sykdoms følgetilstand alvorlig, vil vi overestimere sannsynligheten for diagnosen (angreskjevhet).

Dette er et utvalg av noen diagnostiske skjevheter som er iboende hos alle klinikere. Diagnostiske skjevheter er kognitive skjevheter som alle mennesker har. Vi kan ikke eliminere disse, men gjennom bevisstgjøring kan vi kanskje redusere dem (9).

\section{Resonneringssystemer}

Det er ikke nok at vi bare bevisstgjøres våre svakheter, vi må også være bevisst hvordan vi resonnerer. Vår resonnerende prosess kan deles inn i to systemer: system 1 og system 2 (10). System 1 er den automatiske 
og ubevisste prosessen som er skrudd på hele tiden. System 2 er den bevisste og analyserende prosessen. Vi liker å tro at vi alltid jobber med system 2 , men mesteparten av tiden resonnerer vi med system 1(8). Dette systemet er ikke underlegent, det er effektivt og tidsbesparende, men også tilbøyelig for feilslutninger. I vanskelige situasjoner vil det å innse at vi er på autopilot kunne hjelpe oss til å tenke på problemet analytisk. For eksempel: Har pasienten viral eller bakteriell luftveisinfeksjon? Du vurderer forhold som allmenntilstand, temperatur, lungeauskultasjon, CRP, ekspektorat og hoste. Med system 1 regner vi ubevisst sammen og sannsynliggjør de forskjellige kliniske funnene i lys av pasientens tilstand og sykehistorie og sannsynliggjør automatisk enten bakteriell eller viral agens. Slik som Magnus Carlsen fort vil finne et godt sjakktrekk, så vil en erfaren kliniker gjenkjenne og sammenfatte kliniske funn og sykehistorie. Når klinikken er entydig eller symptomer er patognomiske, er de heuristiske tommelfingerreglene til system 1 tilstrekkelige. Men når funnene er tvetydige eller sannsynligheten for en sykdom er lav, kan dette systemet gi problemer. Når du går inn i diagnostisk grumsete farvann på autopilot, er du i større grad utsatt for ikke ufeilbarlige intuitive statistiske sannsynlighetsvurderinger og kognitive skjevheter. Ved å bytte til system 2 blir du bedre rustet til å møte disse utfordringene. Hva vil det si i praksis? Hvordan skal du i en klinisk hverdag skru på system 2 og praktisere bayesiansk sannsynlighet for å forbedre dine kliniske vurderinger?

\section{En klinisk bayesianer i praksis}

Ikke bli skremt av at det er tall og formler, bayesiansk sannsynlighetsregning er forbausende lett. Her er noen konkrete eksempler. Formelen vi skal bruke er Bayes' regel:

$($ odds før test $) \cdot($ testodds $)=($ odds etter test $)$

Formelen sier at du tar oddsen for sykdom før en test utføres (odds før test) og multipliserer med oddsen for sykdom hvis testen er positiv eller negativ (testodds), noe som da gir en modifisert odds for sykdom (odds etter test). Vi bruker odds fordi det gjør utregningene enklere. Oddsen for en hendelse kan illustreres med at du har en kurv som inneholder tre appelsiner og fem epler. Oddsen for å trekke en appelsin er da 3:5 mens oddsen for å trekke et eple er $5: 3$. Odds er altså definert som forholdet mellom «suksess» og «ikke-suksess»:

odds $=($ suksess $):($ ikke - suksess $)$
Ønsker du å omregne odds til sannsynlighet, så kan det enkelt gjøres slik:

sannsynlighet $=\frac{\text { odds }}{\text { odd } s+1}$

Bruker vi eksemplet med appelsiner og epler, er sannsynligheten for å trekke en appelsin:

sannsynlighet for appelsin

$=\frac{3: 5}{3: 5+1}=\frac{3}{8}=37,5 \%$

La oss regne på et konkret medisinsk eksempel med Bayes' regel (1): Hva er sannsynligheten for at en frisk 25-åring med stikkende brystsmerter skal ha kardial iskemi? Du som kliniker vurderer oddsen før test ved hjelp av klinisk skjønn eller insidensdata. At denne 25-åringen har hjerteiskemi, er en høyst subjektiv vurdering, men det er vist at leger overestimerer heller enn underestimerer sannsynligheten for en sykdom (11). La oss si at oddsen før test er lav, 1:500, og vi lurer på hvordan oddsen for sykdom forandrer seg etter et EKG. I dette tilfellet er EKG testen vi utfører, og denne kan være positiv eller negativ for kardial iskemi. Testodds kalles også sannsynlighetsratio (SR) og beregnes fra testens sensitivitet og spesifisitet. Ut ifra om testen er positiv eller negativ kan man regne ut en positiv $S R(S R+)$ eller negativ $S R(S R \div)$ :

$$
\begin{aligned}
& (S R+)=\frac{\text { sensitivitet }}{(1-\text { spesifisitet })} \\
& (S R \div)=\frac{(1-\text { sensitivitet })}{\text { spesifisitet }}
\end{aligned}
$$

Hvis vi antar at EKG har en sensitivitet og spesifisitet på 0,9 , kan vi regne ut $\mathrm{SR}+$ med ovennevnte formel. Vi får da $(S R+)=9 \mathrm{og}$ $(S R \div)=0,11$.

Vi bruker nå Bayes' regel for å regne ut hva oddsen er for kardial iskemi hvis EKG er positiv for iskemi:

$($ odds etter test $)=($ odds før test $) \cdot(S R+)=$ $(1: 500) \cdot 9=9: 500$

Tabell 1 Behandling av nyresteiner. Tabellen viser hvor mange personer hadde vellykket behandling

\begin{tabular}{lrr}
\hline & Behandling A & Behandling B \\
Små steiner $<2 \mathrm{~cm}$ & $93 \%(81 / 87)$ & $87 \%(234 / 270)$ \\
Store steiner $>2 \mathrm{~cm}$ & $73 \%(192 / 263)$ & $69 \%(55 / 80)$ \\
Begge & $78 \%(273 / 350)$ & $83 \%(289 / 350)$ \\
\hline
\end{tabular}

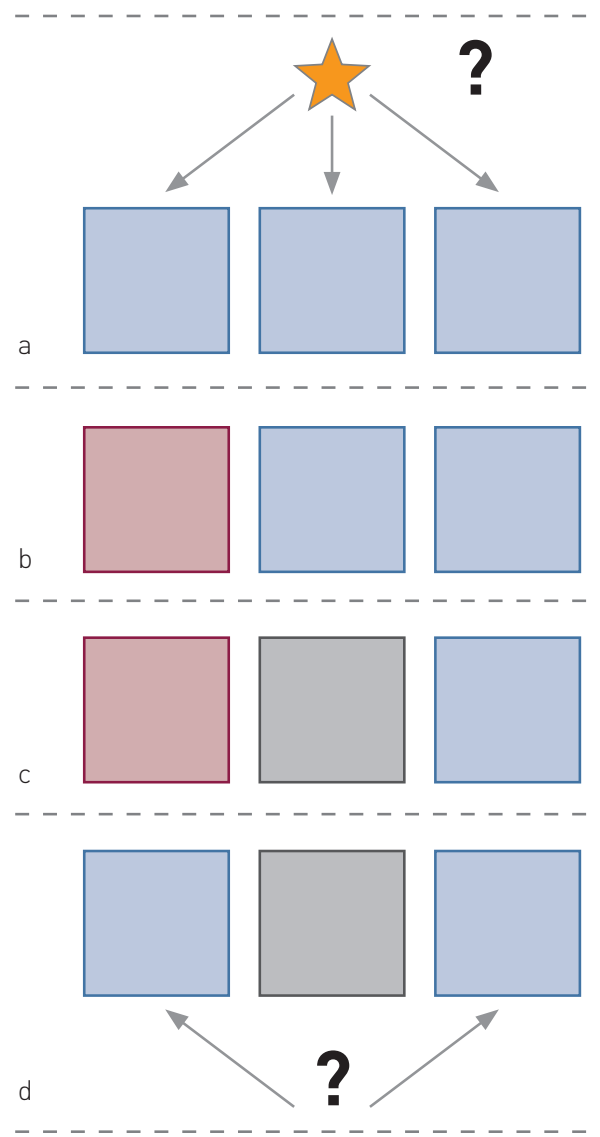

Figur 1 Monty Hall-problemet. Du får presentert tre luker. Bak én av lukene er det en premie, mens de to andre er tomme. al Du har tre valgmuligheter og vet at det er en premie skjult bak en av lukene. b) Du velger en luke (rød), men får ikke avslørt hva som er bak den. c) En av lukene du ikke valgte, blir avslørt å være tom (grå). d) Du kan nå velge å beholde din opprinnelige luke eller å bytte

Selv om EKG er positiv for iskemi, vil oddsen for at det virkelig er kardial iskemi, fremdeles være veldig lav.

La oss nå se på en tidligere hjertesyk 75-åring med trykkende brystsmerter. Som erfaren kliniker har du vurdert at oddsen er $2: 1$ for at han har kardial iskemi. Spørsmålet er hva oddsen vil være for kardial iskemi hvis EKG er negativ. Hvis EKG er negativ, kan vi med Bayes' regel regne ut: 
$($ odds etter test $)=($ odds før test $) \cdot(S R \div)=$ $(2: 1) \cdot 0,11=22: 100$

Man kan omregne oddsen $22: 100$ til 18\% sannsynlighet. Dermed ser vi at selv om EKG er negativ, så er sannsynligheten for kardial iskemi så høy at man burde gjøre tilleggsundersøkelser.

Bayes' regel illustrerer også viktigheten av en god anamnese. La oss si at oddsen for at en pasient har en sykdom er 1:3. Man stiller deretter fem anamnestiske spørsmål som alle var negative med tanke på den antatte sykdommen. For enkelhets skyld kan vi anta at alle de anamnestiske spørsmålene har en $(S R \div)=0,5$. Da får man følgende utregning med Bayes' regel:

$($ odds etter test $)=(1: 3) \cdot 0,5^{5}=1: 96 \approx 1 \%$

Hvis svarene på alle de fem anamnestiske spørsmålene er negative, så faller den antatte oddsen for sykdommen fra 1:3 til 1: 96. En god anamnese kan derfor i stor grad forandre den tentative diagnosen.

\section{En bedre kliniker}

Jeg mener ikke at leger skal gå med en kalkulator i lommen eller at vår intuisjon ikke er til å stole på. Bayes’ teorem er et verktøy vi kan bruke til å konkretisere en sykdoms (u)sannsynlighet, men det er også en konseptuell idé som belyser hvordan vi resonnerer som leger. Målet er å bli bevisst vår måte å resonnere på og våre iboende kognitive skjevheter, slik at vi som klinikere bedre kan forstå og estimere sannsynlighet og unngå feilvurderinger. Vi jobber allerede intuitivt bayesiansk, og skal vi bli bedre, trenger vi bare å tenke høyt litt oftere: Hva er sannsynligheten?

\section{Brage Brakedal (f. 1984)}

har bachelor i matematikk og er lege i spesialisering ved Nevrologisk avdeling. Haukeland universitetssykehus.

Forfatter har fylt ut ICMJE-skjemaet og oppgir ingen interessekonflikter.

\section{Litteratur}

1. Gill CJ Sabin L, Schmid CH. Why clinicians are natural bayesians. BMJ 2005; 330: 1080-3.

2. Naess $H$, Nyland HI, Thomassen $L$ et al. Incidence and short-term outcome of cerebral infarction in young adults in western Norway. Stroke 2002; 33: $2105-8$.

3. Wikipedia. Birthday problem. http://en.wikipedia org/wiki/Birthday_problem (23.4.2015)
4. John T. Behind Monty Hall's doors: puzzle, debate and answer? The New York Times 21.7.1991. www.nytimes.com/1991/07/21/us/ behind-monty-hall-s-doors-puzzle-debate-andanswer.html?pagewanted=1 (23. 4.2015).

5. Wikipedia. Simpsons's paradox. http://en.wikipedia org/wiki/Simpson\%27s paradox (23.4.2015).

6. Charig CR, Webb DR, Payne SR et al. Comparison of treatment of renal calculi by open surgery, percutaneous nephrolithotomy, and extracorporeal shockwave lithotripsy. Br Med J (Clin Res Ed) 1986: 292: 879-82.

7. Bornstein BH, Emler AC. Rationality in medical decision making: a review of the literature on doctors' decision-making biases. J Eval Clin Pract 2001; 7: 97-107.

8. Kahneman D. Thinking, fast and slow. New York, NY: Farrar, Straus and Giroux, 2011.

9. Croskerry P. The importance of cognitive errors in diagnosis and strategies to minimize them. Acad Med 2003. 78. 775-80.

10. Stanovich KE, West RF. Individual differences in reasoning: implications for the rationality debate? Behav Brain Sci 2000; 23: 645-65, discussion $665-726$

11. Cahan A, Gilon D, Manor 0 et al. Probabilistic reasoning and clinical decision-making: do doctors overestimate diagnostic probabilities? QJM 2003; 96: 763-9.

Mottatt 21.5. 2015, første revisjon innsendt 25.6 2015, godkjent 25.6. 2015. Redaktør: Inge Rasmus Groote. 